OPEN ACCESS

Edited and reviewed by:

Ana Traven,

Monash University, Australia

*Correspondence:

Rebeca Alonso-Monge

realonso@ucm.es

${ }^{\dagger}$ Present Address:

Inês Correia

Instituto de Biologia Molecular e Celular, Instituto para a Investigação e

Inovação em Saúde - i3S, Porto,

Portugal

Specialty section:

This article was submitted to

Fungi and Their Interactions,

a section of the journal

Frontiers in Microbiology

Received: 01 February 2017

Accepted: 16 March 2017

Published: 13 April 2017

Citation:

Correia I, Alonso-Monge $R$ and Pla $J$ (2017) Corrigendum: The Hog1 MAP Kinase Promotes the Recovery from

Cell Cycle Arrest Induced by

Hydrogen Peroxide in Candida albicans. Front. Microbiol. 8:555. doi: 10.3389/fmicb.2017.00555

\section{Corrigendum: The Hog1 MAP Kinase Promotes the Recovery from Cell Cycle Arrest Induced by Hydrogen Peroxide in Candida albicans}

\author{
Inês Correia ${ }^{\dagger}$, Rebeca Alonso-Monge * and Jesús Pla \\ Departamento de Microbiología II, Facultad de Farmacia, Universidad Complutense de Madrid, Madrid, Spain \\ Keywords: Candida albicans, cell cycle, oxidative stress, signaling, MAPK
}

\section{A corrigendum on}

The Hog1 MAP Kinase Promotes the Recovery from Cell Cycle Arrest Induced by Hydrogen Peroxide in Candida albicans

by Correia, I., Alonso-Monge, R., and Pla, J. (2017). Front. Microbiol. 7:2133. doi: 10.3389/fmicb. 2016.02133

In the original article, there was a mistake in Figure $2 \mathrm{C}$ as published. Histograms in the lower row did not belong to the experiment described in the manuscript. The corrected Figure 2 appears below. The authors apologize for this error and state that this does not change the scientific conclusions of the article in any way.

Conflict of Interest Statement: The authors declare that the research was conducted in the absence of any commercial or financial relationships that could be construed as a potential conflict of interest.

Copyright () 2017 Correia, Alonso-Monge and Pla. This is an open-access article distributed under the terms of the Creative Commons Attribution License (CC BY). The use, distribution or reproduction in other forums is permitted, provided the original author(s) or licensor are credited and that the original publication in this journal is cited, in accordance with accepted academic practice. No use, distribution or reproduction is permitted which does not comply with these terms. 
A

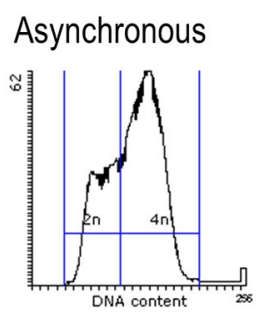

2n $30 \%$

4n $68 \%$
Synchronous

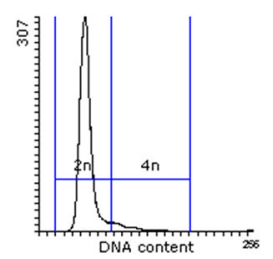

2n $94 \%$

4n $6 \%$

\section{B}

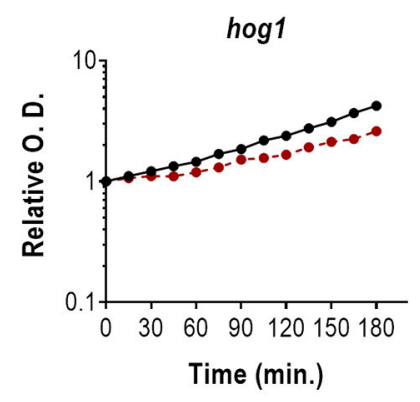

$45^{\prime}$

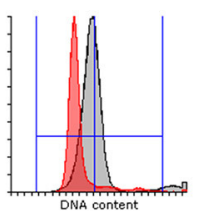

$165^{\prime}$

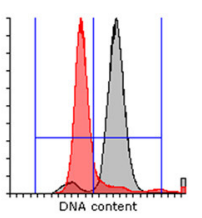

$180^{\prime}$

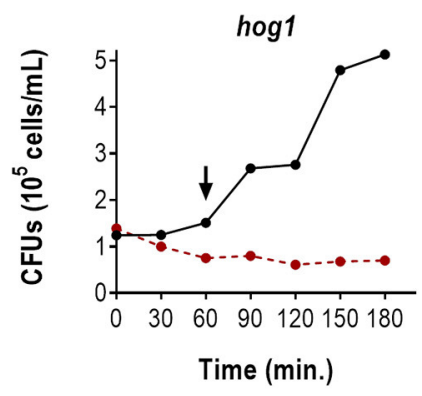

$7^{\prime}$
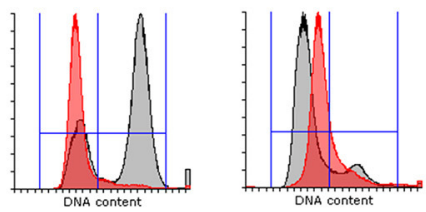

$120^{\prime}$ $135^{\prime}$

$150^{\prime}$
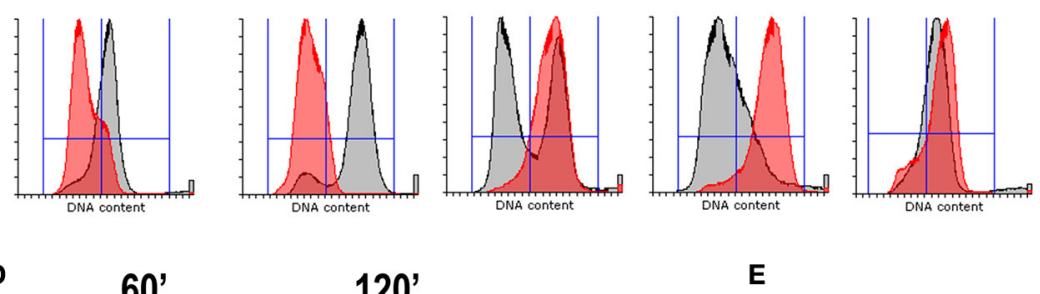

D

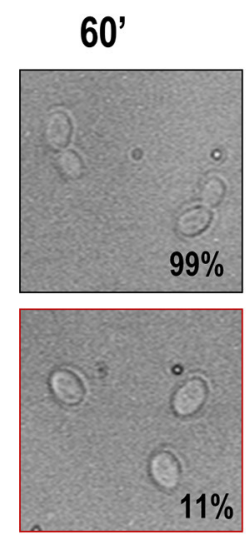

$120^{\prime}$
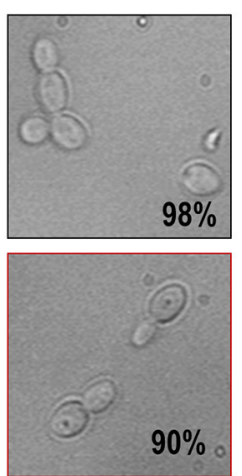

E

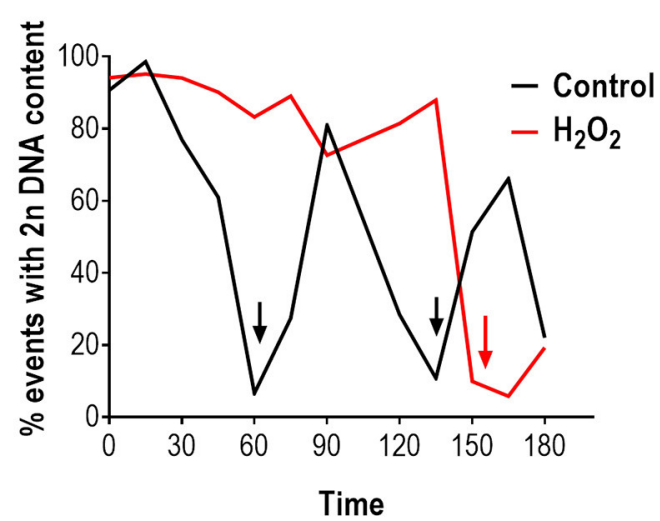

FIGURE 2 | Effect of $\mathrm{H}_{2} \mathrm{O}_{2}$ on cell cycle progression in the hog1 mutant. (A) Flow cytometry analysis of hog1 mutant cells before and after elutriation. The percentage of cells with $2 \mathrm{n}$ and $4 \mathrm{n}$ DNA content are indicated. (B) After elutriation, $\mathrm{G} 1$ synchronized cells were released in $\mathrm{YPD}$ at $37^{\circ} \mathrm{C}$ with or without $1 \mathrm{mM} \mathrm{H}_{2} \mathrm{O}_{2}$. The growth was followed over time and depicted as relative O.D. (left panel) or CFUs vs. time (right panel). The black line represents cultures without stress, while the red line represents cultures in the presence of $\mathrm{H}_{2} \mathrm{O}_{2}$. The arrow marks cytokinesis. (C) Histograms of cultures released in the presence (red) or absence (gray) of oxidative stress at the indicated time. (D) Representative pictures of the culture without stress (upper row, black frame) or with an oxidative agent (1 $\mathrm{mM} \mathrm{H}_{2} \mathrm{O}_{2}$, lower row, red frame). The percentage of budding is indicated for each condition. (E) The percentage of cells with $2 n$ DNA content is plotted vs. time for cultures released with and without stress. Arrows indicate 4n DNA content. 